\title{
Vasoactive intestinal peptide receptors in the airways of smokers with chronic bronchitis
}

\author{
D. Miotto*, P. Boschetto*, I. Bononi*, E. Zeni*, G. Cavallesco", L.M. Fabbri", C.E. Mapp*
}

Vasoactive intestinal peptide receptors in the airways of smokers with chronic bronchitis. D. Miotto, P. Boschetto, I. Bononi, E. Zeni, G. Cavallesco, L. M. Fabbri, C.E. Mapp. (C) ERS Journals Ltd 2004.

ABSTRACT: Vasoactive intestinal peptide (VIP) is a neuropeptide involved in the regulation of airway mucus secretion. The biological functions of VIP are mediated through two receptors, the vasoactive intestinal peptide receptor type 1 (VPAC1R) and type 2 (VPAC2R). The aim of this study was to quantify the expression of both VPAC1R and VPAC2R in the central airways of smokers with chronic bronchitis.

Surgical specimens were obtained from 33 smokers undergoing thoracotomy for localised pulmonary lesions: 23 smokers with symptoms of chronic bronchitis and 10 asymptomatic smokers with normal lung function.

By using immunohistochemical and microscopic analysis, an increased expression of VPAC1R, but not VPAC2R, was found in bronchial epithelium, bronchial glands and vessels of smokers with symptoms of chronic bronchitis compared with asymptomatic smokers. Smokers with symptoms of chronic bronchitis also had an increased number of mononuclear cells positive for both VPAC1R and VPAC2R in the bronchial submucosa.

In conclusion, the expression of type 1 and type 2 vasoactive intestinal peptide receptors is increased in the central airways of smokers with chronic bronchitis, suggesting their possible involvement in the pathogenesis of chronic bronchitis. Eur Respir J 2004; 24: 958-963.
Depts of * Clinical and Experimental Medicine and ${ }^{\#}$ Surgery, Anaesthesiology and Radiology, University of Ferrara, Ferrara, and "Dept of Respiratory Diseases, University of Modena and Reggio Emilia, Modena, Italy.

Correspondence: C.E. Mapp, Dipartimento di Medicina Clinica e Sperimentale, Sezione di Igiene e Medicina del Lavoro, via Fossato di Mortara 64/b, 44100 Ferrara, Italy.

Fax: 390532205066

E-mail: map@unife.it

Keywords: Mucus secretion, neuropeptide receptors, vasoactive intestinal peptide

Received: March 152004

Accepted after revision: August 122004

This study was supported by Consorzio Ferrararicerche (Ferrara, Italy), MURST (Minister of University and Scientific Research, Rome, Italy), and ARCA (Associazione per la Ricerca e la Cura dell'Asma, Padova, Italy).
Vasoactive intestinal peptide (VIP) is a member of the secretin family of peptides. It is one of the most important nonadrenergic, noncholinergic inhibitory transmitters in the lung, where it is involved in the control of airway tone, vascular relaxation and mucus secretion [1-3]. In the respiratory system of humans, VIP-containing nerve fibres have been described in tracheo-bronchial smooth muscle, around submucosal glands and in the walls of pulmonary and bronchial vessels [4].

Two types of VIP receptors have been cloned and characterised $[5,6]$. They are termed the vasoactive intestinal peptide receptor type 1 (VPAC1R) and type 2 (VPAC2R), and both belong to the $\mathrm{G}$ protein-coupled receptor family $[6,7]$. Both VPAC1R and VPAC2R are expressed in human airways $[8,9]$ : VPAC1R by bronchial epithelial cells, bronchial and vascular smooth muscle [5], and VPAC2R by bronchial epithelial cells and bronchial glands [9].

Previously, an increased density of VIP-immunoreactive nerves has been shown in the bronchial glands of smokers with chronic bronchitis as compared with asymptomatic smokers [10], supporting a role of VIP in mucus hypersecretion, which is the distinctive feature of chronic bronchitis. To further investigate this hypothesis, in the present study, the expression of VPAC1R and VPAC2R in the central airways of patients with chronic bronchitis was quantified.
Methods

\section{Subjects}

Lung specimens obtained from smokers undergoing thoracotomy for localised pulmonary lesions were examined, as follows: 23 smokers with symptoms of chronic bronchitis (10 with chronic airflow obstruction and 13 with normal lung function), and 10 asymptomatic smokers with normal lung function. Due to the lack of a sufficient number of tissue sections, the expression of VPAC2R was assessed in the following subgroup of subjects: 17 smokers with symptoms of chronic bronchitis (patient Nos 1-17, table 1) and eight asymptomatic smokers (patient Nos 24-31, table 1). For the same reason, VPAC1R immunostaining was not done in patient Nos 30 and 31 (table 1).

Chronic bronchitis and chronic airflow obstruction were defined according to the American Thoracic Society criteria and Global Initiative for Chronic Obstructive Lung Disease (GOLD) guidelines, respectively [11, 12]. The study conformed to the Declaration of Helsinki, and all the patients gave their informed written consent.

All the subjects had been free of acute upper respiratory tract infections and did not receive glucocorticoids or antibiotics within the month preceding surgery or bronchodilators within the previous $48 \mathrm{~h}$. They had not had 
Table 1.-Characteristics of smokers with symptoms of chronic bronchitis (CB) and asymptomatic smokers (AS)

\begin{tabular}{lccccc}
\hline Patient No. Sex & $\begin{array}{c}\text { Age } \\
\text { yrs }\end{array}$ & $\begin{array}{c}\text { Smoking } \\
\text { history } \\
\text { pack-yrs/yrs }\end{array}$ & $\begin{array}{c}\text { FEV1 } \\
\% \text { pred }\end{array}$ & $\begin{array}{c}\text { FEV1/FVC } \\
\%\end{array}$ \\
\end{tabular}

\begin{tabular}{|c|c|c|c|c|c|}
\hline \multicolumn{6}{|l|}{$\mathrm{CB}$} \\
\hline 1 & $\mathrm{M}$ & 69 & $25 / 51$ & 89 & 66 \\
\hline 2 & $\mathrm{M}$ & 63 & $45 / 40$ & 79 & 69 \\
\hline 3 & M & 68 & $50 / 50$ & 73 & 64 \\
\hline 4 & $\mathrm{M}$ & 84 & $61 / 61$ & 62 & 69 \\
\hline 5 & $\mathrm{M}$ & 57 & $88 / 44$ & 78 & 69 \\
\hline 6 & $\mathrm{M}$ & 74 & $58 / 50$ & 56 & 64 \\
\hline 7 & M & 75 & $100 / 50$ & 77 & 62 \\
\hline 8 & M & 63 & $16 / 50$ & 78 & 75 \\
\hline 9 & M & 57 & $94 / 47$ & 91 & 70 \\
\hline 10 & M & 65 & $52 / 52$ & 80 & 84 \\
\hline 11 & $\mathrm{M}$ & 75 & $55 / 64$ & 97 & 71 \\
\hline 12 & M & 58 & $32 / 43$ & 105 & 82 \\
\hline 13 & M & 68 & $43 / 58$ & 68 & 72 \\
\hline 14 & M & 58 & $31 / 42$ & 75 & 70 \\
\hline 15 & M & 74 & & 98 & 69 \\
\hline 16 & M & 76 & $60 / 60$ & 71 & 74 \\
\hline 17 & M & 78 & $38 / 38$ & 83 & 74 \\
\hline 18 & M & 72 & $100 / 39$ & 57 & 54 \\
\hline 19 & $\mathrm{M}$ & 66 & $78 / 52$ & 68 & 67 \\
\hline 20 & $\mathrm{M}$ & 80 & $18 / 52$ & 130 & 90 \\
\hline 21 & $\mathrm{M}$ & 58 & $46 / 12$ & 83 & 72 \\
\hline 22 & M & 67 & $49 / 49$ & 99 & 74 \\
\hline 23 & M & 72 & $42 / 54$ & 115 & 101 \\
\hline Mean \pm SEM & & $69 \pm 2$ & $54 \pm 5 / 48 \pm 2 *$ & $83 \pm 4 * *$ & $72 \pm 2$ \\
\hline \multicolumn{6}{|l|}{ AS } \\
\hline 24 & $\mathrm{M}$ & 72 & $65 / 20$ & 108 & 72 \\
\hline 25 & M & 66 & $45 / 45$ & 108 & 76 \\
\hline 26 & M & 65 & $48 / 32$ & 86 & 76 \\
\hline 27 & M & 81 & $60 / 30$ & 116 & 91 \\
\hline 28 & $\mathrm{M}$ & 64 & $47 / 47$ & 93 & 74 \\
\hline 29 & $\mathrm{M}$ & 56 & $29 / 39$ & 101 & 75 \\
\hline 30 & M & 65 & $47 / 47$ & 97 & 80 \\
\hline 31 & $\mathrm{~F}$ & 44 & $1 / 28$ & 105 & 81 \\
\hline 32 & M & 70 & $54 / 54$ & 86 & 82 \\
\hline 33 & M & 68 & $35 / 35$ & 102 & 70 \\
\hline Mean \pm SEM & & $65 \pm 3$ & $47 \pm 4 / 38 \pm 3$ & $100 \pm 3$ & $78 \pm 2$ \\
\hline
\end{tabular}

Data are presented as $\mathrm{n}$ and mean \pm SEM, unless otherwise stated. FEV1: forced expiratory volume in one second; $\%$ pred: $\%$ predicted; FVC: forced vital capacity; M: male; F: female. ${ }^{*}: \mathrm{p}<0.05$; ${ }^{* *}: \mathrm{p}<0.01$ versus asymptomatic smokers.

exacerbations, as previously defined [13], during the month before the study. The patients were nonatopic (i.e. they had a negative skin test for common allergen extracts) and had no past history of asthma or allergic rhinitis.

Each subject underwent an interview, chest radiography, ECG, routine blood tests, skin tests with common allergen extracts and spirometry in the week before surgery. Spirometry was performed as described previously [13].

\section{Immunohistochemical quantification of vasoactive intestinal peptide receptors}

Bronchial rings (lobar or segmental bronchus) were taken from the lobe obtained at surgery, avoiding areas involved by the tumour. Samples were fixed in $4 \%$ formaldehyde in PBS at pH 7.2 and, after dehydration, embedded in paraffin wax. Sections $(5-\mu \mathrm{m}$ thick) were cut and subsequently hydrated. Endogenous peroxidase activity was blocked by immersing slides in $0.3 \%$ hydrogen peroxide in methanol. Slides were then incubated in normal rabbit serum diluted in tris buffered saline (TBS). Anti-human VPAC1R and VPAC2R antibodies
Table 2.-Vasoactive intestinal peptide receptor type 2 (VPAC2R) expression in the central airways of smokers

\begin{tabular}{|c|c|c|}
\hline & $\begin{array}{l}\text { Smokers with } \\
\text { symptoms of } \\
\text { chronic bronchitis }\end{array}$ & $\begin{array}{l}\text { Asymptomatic } \\
\text { smokers }\end{array}$ \\
\hline $\begin{array}{l}\text { VPAC2R-positive } \\
\text { epithelial cells } \cdot \mathrm{mm}^{-1} \\
\text { basement membrane }\end{array}$ & $77.3(38.4-196.6)^{\#}$ & $62.4(17.9-130.4)^{\bullet}$ \\
\hline $\begin{array}{l}\text { VPAC2R-positive } \\
\text { mononuclear cells } \cdot \mathrm{mm}^{-2} \\
\text { submucosa }\end{array}$ & $25.1(9.3-56.8)^{*,+}$ & $5.1(0.51-18.4)^{\S}$ \\
\hline $\begin{array}{l}\text { VPAC2R-positive } \\
\text { acini/total acini } \%\end{array}$ & $49.7(24.3-73.1)^{\#}$ & $51.3(36.4-62.1)^{\oplus}$ \\
\hline $\begin{array}{l}\text { VPAC2R-positive } \\
\text { vessels/total vessels \% }\end{array}$ & $13.3(6.3-22.6)^{+}$ & $16.3(2.0-27.5)^{\S}$ \\
\hline $\begin{array}{l}\text { VPAC2R-positive } \\
\text { smooth muscle } \\
\text { area/bronchial } \\
\text { wall area } \%\end{array}$ & $0.7(0.5-2.1)^{f}$ & $0.6(0.1-1.7)^{\S}$ \\
\hline
\end{tabular}

Data are expressed as median (interquartile range). VPAC2R quantification in the bronchial glands of subject Nos 13 and 33, in the bronchial epithelium of subject Nos 12 and 26 and in the bronchial smooth muscle of subject Nos 8 and 14 could not be performed. *: $\mathrm{p}<0.05$ versus asymptomatic smokers; ${ }^{\#}: \mathrm{n}=17{ }^{\uparrow}: \mathrm{n}=7 ;^{+}: \mathrm{n}=18 ;{ }^{\S}: \mathrm{n}=8$; $f: \mathrm{n}=16$.

(1:40 and 1:30 in TBS, respectively; code Z135M and Z140M; Exalpha Biological Inc., Boston, MA, USA) were applied overnight at $4^{\circ} \mathrm{C}$. Sections were subsequently incubated with biotinylated rabbit anti-mouse immunoglobulin G (E413; Dako Ltd., Glostrup, Denmark) and with streptavidinbiotin-complex reagent conjugated to horseradish peroxidase (StreptABComplex/HRP; K0377; Dako). Immunoreactivity was visualised with diaminobenzidine. Sections were counterstained with haematoxylin, dehydrated, and mounted in Eukitt (Kindlex GMBH, Freiburg, Germany). Negative controls were performed by omission of the primary antibody.

Slides were coded, and the expression of the receptors in the bronchial glands, vessels and inflammatory cells in the bronchial submucosa was quantified using an Olympus BX41 microscope (Olympus Optical Co., Hamburg, Germany), as previously described $[14,15]$. The receptors were quantified in bronchial epithelium and smooth muscle with an image analysis system (Image-Pro plus; Media Cybernetics Inc., Silver Spring, MD, USA) [14]. A magnification of $600 \times$ was used for bronchial epithelium, glands and inflammatory cells, of $400 \times$ (in the area $300 \mu \mathrm{m}$ beneath the epithelial basement membrane) for vessels and of $200 \times$ for bronchial smooth muscle. Results were expressed as the following: number of bronchial epithelial cells expressing VPAC1R or VPAC2R $\cdot \mathrm{mm}^{-1}$ basement membrane; number of VPAC1R- or VPAC2R-positive mononuclear cells $\cdot \mathrm{mm}^{-2}$ bronchial submucosa; $\%$ of VPAC1R- or VPAC2R-positive acini/total acini; $\%$ of VPAC1R- or VPAC2R-positive vessels/total vessels; \% of bronchial smooth muscle area VPAC1R- or VPAC2R-positive/total bronchial wall area. The quantification of VIP receptors was satisfactory in the majority of samples. In some patients, quantification of receptors in bronchial epithelium, glands or smooth muscle was not performed because the morphology of the structure examined was not satisfactory, or because the number of microscopic fields in that structure was not sufficient for quantification (table 2; figs 1 and 2).

\section{Statistical analysis}

Group data were expressed as mean \pm SEM or as medians (interquartile ranges) when appropriate. Unpaired t-test 

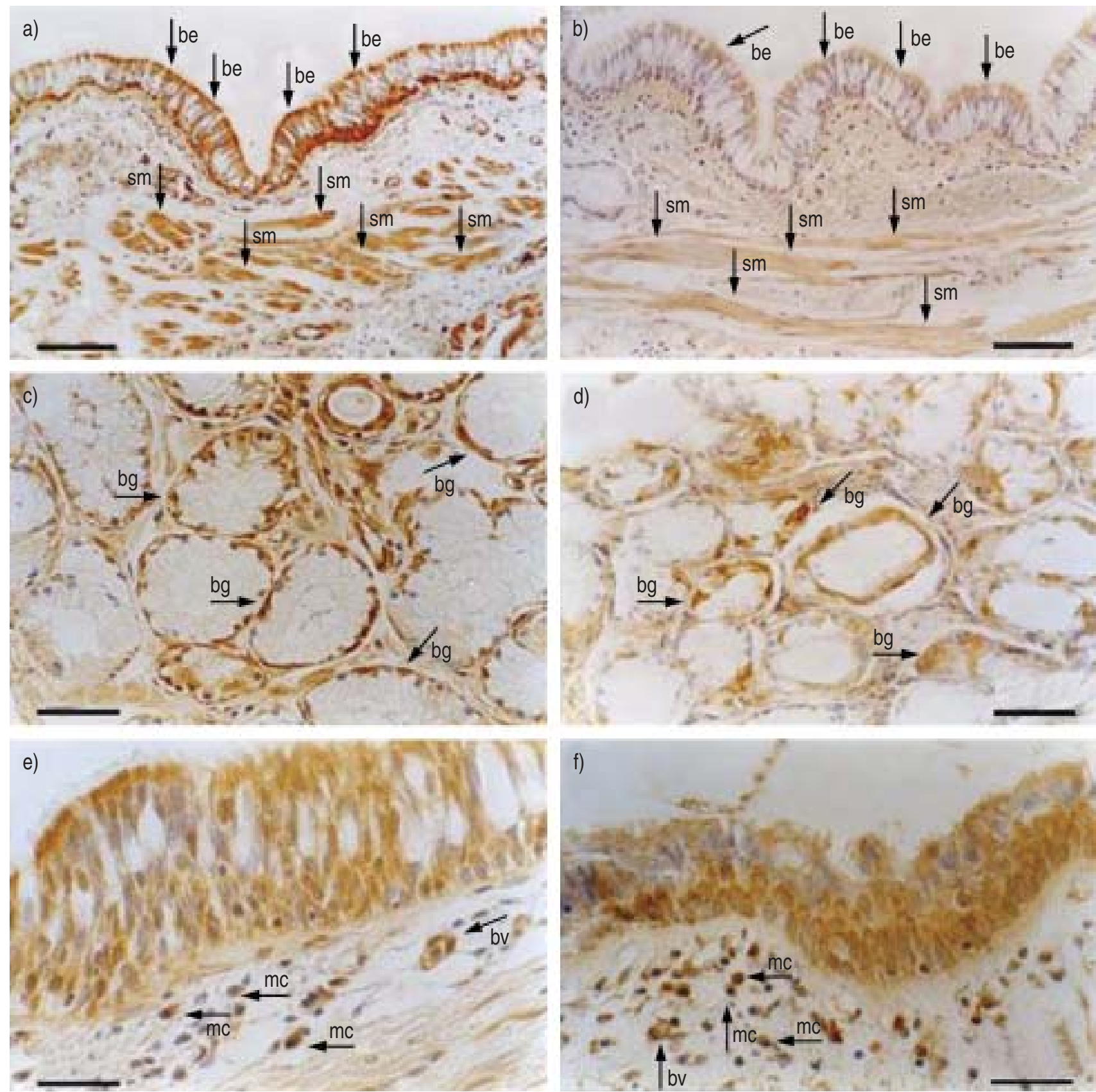

Fig. 1. - Light microscopic analysis of immunostained central airways of a smoker with chronic bronchitis showing expression of a) vasoactive intestinal peptide receptor type 1 (VPAC1R) and b) type 2 (VPAC2R) by bronchial epithelium (be) and smooth muscle (sm), c) VPAC1R and d) VPAC2R by bronchial glands (bg), and e) VPAC1R and f) VPAC2R by bronchial vessels (bv) and mononuclear cells infiltrating the bronchial submucosa $(\mathrm{mc})$. Arrows indicate positive immunostaining. Sections were immunostained with monoclonal antibodies specific for human VPAC1R and VPAC2R. Scale bars $=100(\mathrm{a}$ and b), 50 (c and d) and $30 \mu \mathrm{m}$ (e and $\mathrm{f}$ ).

analysis for clinical data and the Mann-Whitney U-test for histological data were used to determine differences between groups. Spearman's rank correlation test was used to examine the association between immunohistochemical measurements and clinical data. Probability values of $\leqslant 0.05$ were accepted as significant. At least two replicate measurements were performed blindly by the same observer in 10 randomly selected slides. The intra-observer coefficient of variation ranged $4-14 \%$ for bronchial epithelium, $5-13 \%$ for glands, $10-14 \%$ for vessels, $10-15 \%$ for smooth muscle, and $7-14 \%$ for inflammatory cells.

\section{Results}

\section{Clinical findings}

Table 1 shows the characteristics of the subjects examined. The two groups of smokers were similar with regards to age and number of pack-yrs. Smokers with symptoms of chronic bronchitis had a significantly longer smoking history $(\mathrm{p}<0.05$; table 1) and a lower baseline forced expiratory volume in one second (FEV1) \% predicted ( $<<0.01$; table 1$)$ than asymptomatic smokers. 

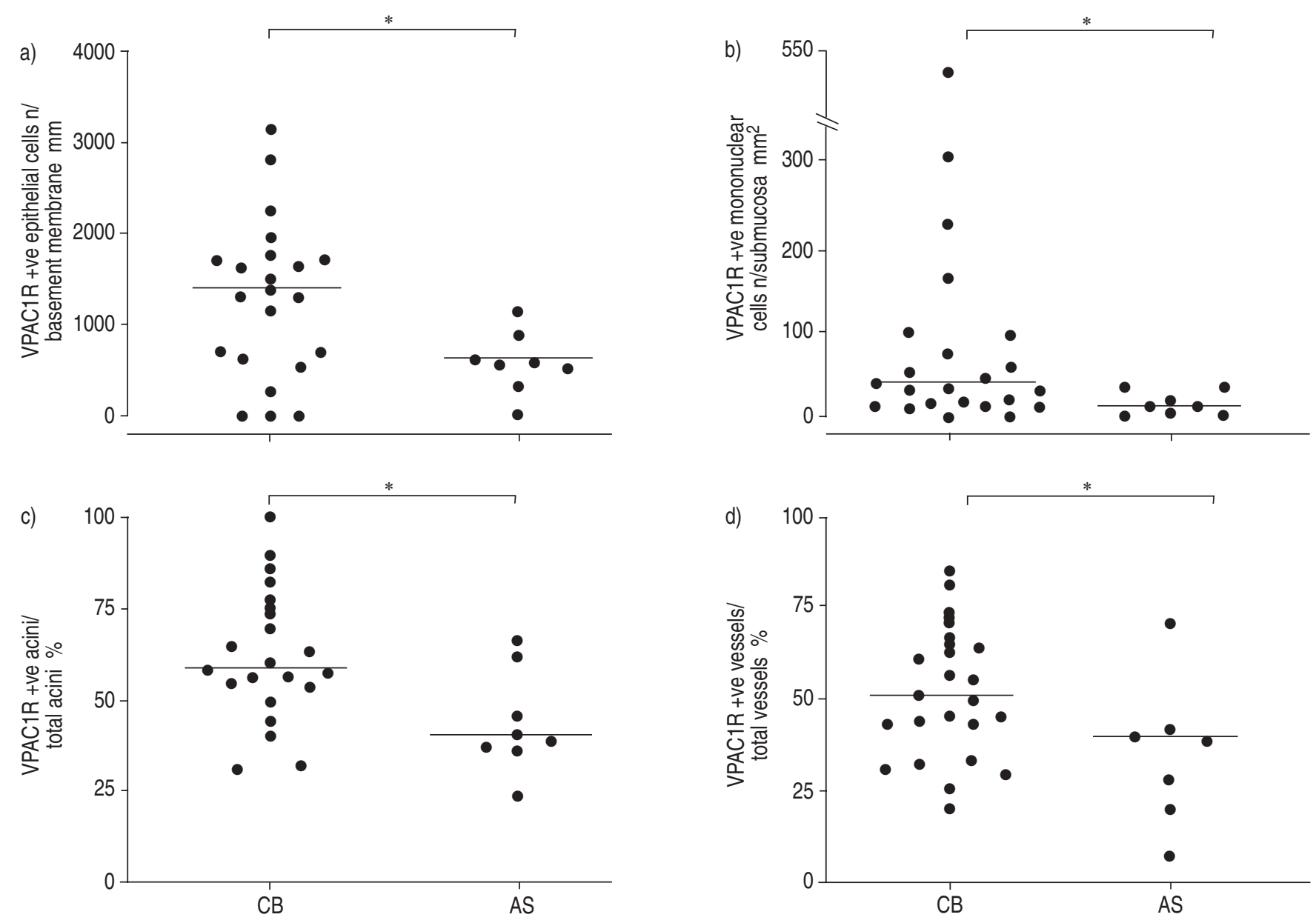

Fig. 2.-Individual values of vasoactive intestinal peptide receptor type 1 (VPAC1R) expression in bronchial epithelium, mononuclear cells infiltrating the bronchial submucosa, bronchial glands, and vessels of smokers. Horizontal bars represent median values. Quantification of VPAC1R expression could not be performed in bronchial epithelium of subject No. 12, in bronchial glands of subject Nos 13 and 20 , and in bronchial vessels of subject No. 26. +ve: positive; CB: smokers with symptoms of chronic bronchitis; AS: asymptomatic smokers. *: p<0.05.

\section{Immunohistochemical findings}

Vasoactive intestinal peptide receptor type 1 . VPAC1Rpositive immunostaining was observed in both basal and columnar bronchial epithelial cells, the mononuclear cells infiltrating the bronchial submucosa, the acini of bronchial glands, bronchial vessels, and bronchial smooth muscle (fig. 1).

Smokers with symptoms of chronic bronchitis had an increased expression of VPAC1R in the bronchial epithelium (median (interquartile range) 1375.6 (664.6-1751.3) VPAC1R-positive cells $\cdot \mathrm{mm}^{-1}$ basement membrane versus 612.6 (465.2-792.1); $\mathrm{p}<0.05)$, bronchial glands $(58.3 \%$ (53.1-75.0\%) VPAC1R-positive acini/total acini versus $40.4 \%$ $(37.5-54.5 \%) ; \mathrm{p}<0.05)$, and vessels $(50.4 \% \quad(36.7-64.1 \%)$ VPAC1R-positive vessels/total vessels versus $39.4 \%(22.8 \%-$ $42 \%$ ); $\mathrm{p}<0.05)$ as compared with asymptomatic smokers. Similarly, the number of VPAC1R-positive mononuclear cells was higher in subjects with chronic bronchitis (34.7 (13.8-94.0) VPAC1R-positive cells $\cdot \mathrm{mm}^{-2}$ of bronchial submucosa versus 6.3 (1.6-23.3); $\mathrm{p}<0.05$; fig. 2). Conversely, the expression of VPAC1R in bronchial smooth muscle was similar in smokers with and without symptoms of chronic bronchitis $(1.1 \%(0.1-3 \%)$ VPAC1R-positive smooth muscle area/bronchial wall area versus $0.8 \%(0.2-1.1 \%))$. No correlations were found between VPAC1R expression and clinical characteristics of the subjects in any airway compartment.
Vasoactive intestinal peptide receptor type 2. VPAC2Rpositive immunostaining was observed in the same airway structures expressing VPAC1R, as follows: basal and columnar bronchial epithelial cells, mononuclear cells infiltrating the bronchial submucosa, acini of bronchial glands, bronchial vessels and bronchial smooth muscle (fig. 1).

However, only the number of VPAC2R-positive mononuclear cells was significantly higher in smokers with chronic bronchitis than in asymptomatic smokers $(\mathrm{p}<0.05$; table 2$)$.

When all the subjects were considered together, the number of VPAC2R-positive mononuclear cells infiltrating the bronchial submucosa showed a negative correlation with FEV1 \% pred $(p<0.01, \rho=-0.531)$. Moreover, in smokers with symptoms of chronic bronchitis, the \% of VPAC2R-positive bronchial vessels showed a negative correlation with the number of years of smoking $(p<0.05, \rho=-0.618)$.

\section{Discussion}

In the present study, an increased expression of VPAC1R in human central airways and an increased number of VPAC2R-positive mononuclear cells in the bronchial submucosa of smokers with symptoms of chronic bronchitis were found.

By using immunohistochemistry, VPAC1R and VPAC2R 
were detected in human bronchial epithelium, mononuclear cells infiltrating the bronchial submucosa, bronchial glands, vessels and bronchial smooth muscle. These localisations are consistent with the airway compartments where VIP exerts its biological functions, and confirm and extend previous findings. Both VPAC1R and VPAC2R mRNA have been detected in human bronchial epithelial cells [7, 9]; VIP receptors have been observed in human bronchial smooth muscle and submucosal glands using autoradiographical techniques, and VPAC2R mRNA has been found in serous and mucous cells of the bronchial glands [9, 16]. In human airways, both VPAC1R and VPAC2R proteins have been detected in the wall of blood vessels, lymphocytes and macrophages [8].

VPAC1R has a high affinity for VIP, which is one of the most abundant neuropeptides found in the lung [17]. An increased expression of a receptor can theoretically amplify the biological actions of its agonist. In the current study, an increased expression of VPAC1R in bronchial epithelium and glands and an increased number of VPAC1R-positive mononuclear cells in the central airways of chronic bronchitics were observed. These findings could suggest a role of the VIP/VPAC1R axis in the regulation of mucus hypersecretion, both directly and indirectly.

In vitro, VIP induces chloride secretion by the human bronchial epithelium and stimulates ciliary motility in rabbitcultured tracheal epithelium, increasing both water secretion and mucociliary clearance [18, 19]. VIP can also stimulate epithelial mucin genes' expression, inducing the release of interleukin (IL)-6 by the human bronchial epithelial cells [20, 21].

The effects of VIP on submucosal glands are opposite. At the pre-junctional level, VIP exerts an inhibitory effect on mucus secretion, decreasing the release of acetylcholine by cholinergic nerves [22]. At the post-junctional level, VIP stimulates mucus secretion acting on receptors expressed by submucosal glands [22]. The final effect of VIP is determined by a balance between pre-junctional inhibition and postjunctional stimulation [22]. In a previous study, it was hypothesised that endogenous VIP released during nerve stimulation causes an increase in mucus secretion, as an increase of VIP-positive nerve density was shown in the glands of chronic bronchitics [10]. Now, the current authors have demonstrated an increased VPAC1R expression in the submucosal glands of subjects with chronic bronchitis, supporting an amplification of the VIP post-junctional effects, i.e. an increase of airway secretion.

The numbers of VPAC1R- and VPAC2R-positive mononuclear cells were increased in the bronchial submucosa of smokers with symptoms of chronic bronchitis. VIP exerts many immunomodulatory properties, regulating both natural and acquired immunity in an autocrine/paracrine manner [23]. VPAC1R is expressed by human resting T-cells and macrophages. Low levels of VPAC2R are expressed by resting T-cells and they increase following stimulation, whilst the expression of VPAC1R decreases [24]. Findings in human peripheral blood lymphocytes suggest that VPAC1R activation can stimulate normal T- and B-cell chemotaxis [25], and this observation can partly explain the finding of an increased number of VPAC1R-positive mononuclear cells in the bronchial submucosa of those with bronchitis.

It has been demonstrated that, in activated macrophages, VIP diminishes the secretion of proinflammatory cytokines and increases the secretion of anti-inflammatory cytokines $[26,27]$. In T-lymphocytes, VIP inhibits the secretion of IL-2 [28]. Therefore, it is reasonable that an increased number of cells expressing VIP receptors could counteract, at least in part, the effects of an excessive inflammation in the airways. VIP can also influence the differentiation of T-cells, promoting the secretion of T-helper (Th) 2 cytokines, such as IL-4 and IL-5, and inhibiting the secretion of Th1 cytokines, such as interferon (IFN)- $\gamma$ [29]. This effect is probably mainly mediated by VPAC2R [30]. Recently, it has been shown that, in the bronchial submucosa of patients with chronic bronchitis, there are an increased number of inflammatory cells expressing IL-4 and IL-13, Th2 cytokines capable of stimulating mucus secretion [15]. Taken together, these data would suggest that inflammatory cells expressing VIP receptors drive the expression of Th2 cytokines in the submucosa of bronchitics, contributing indirectly to mucus hypersecretion.

Traditionally, VIP is believed to be a "defensive" peptide in the lung. Indeed, VIP prevents acute lung injury and improves survival in a variety of experimental models of acute respiratory distress syndrome and sepsis [31, 32], and the VPAC1R seems to be the major mediator of the antiinflammatory actions of VIP [33].

The fact that VIP and its receptors seem to promote mucus hypersecretion, contributing to the pathogenesis of chronic bronchitis, is not in contrast with its defensive role in the airways. Indeed, mucus secretion is a defensive mechanism through which the airways respond to external noxious stimuli, such as cigarette smoke. It can be speculated that airway chronic inflammation could excessively stimulate and perpetuate this defensive mechanism, leading to the development of chronic bronchitis.

The finding of an increased expression of VPAC1R in bronchial vessels of bronchitics suggests that the airway inflammatory process also involves the bronchial circulation. It needs to be further investigated whether the VIP/VPAC1R axis exerts a defensive role in this airway compartment.

In conclusion, the current authors have found that the expression of vasoactive intestinal peptide receptor type 1 is increased in the bronchial epithelium, glands and vessels in the central airways of smokers with chronic bronchitis. Increased numbers of vasoactive intestinal peptide receptor type 1- and 2-positive mononuclear cells were also found in the bronchial submucosa of these patients. The current results suggest that vasoactive intestinal peptide and its receptors may contribute to the pathogenesis of chronic bronchitis, especially to the mechanisms regulating mucus secretion.

\footnotetext{
Acknowledgements. The authors would like to thank C. Piola and A. Rambaldi for their expert collaboration, and G. Fulgeri and E. Veratelli for typing the manuscript.
}

\section{References}

1. Palmer JBD, Cuss FMC, Barnes PJ. VIP and PHM and their role in nonadrenergic inhibitory responses in isolated human airways. J Appl Physiol 1986; 61: 1322-1328.

2. Coles SJ, Said SI, Reid LM. Inhibition by vasoactive intestinal peptide of glucoconjugate and lysozyme secretion by human airways in vitro. Am Rev Respir Dis 1981; 124 : $531-536$

3. Greenberg B, Rhoden K, Barnes PJ. Relaxant effects of vasoactive intestinal peptide and peptide histidine isoleucine in human and bovine pulmonary arteries. Blood Vessels 1987; 24: 45-50.

4. Barnes PJ, Baraniuk JN, Belvisi MG. Neuropeptides in the respiratory tract. Part I. Am Rev Respir Dis 1991; 144: 11871198.

5. Ishihara T, Shigemoto R, Mori K, Takahashi K, Nagata S. Functional expression and tissue distribution of a novel 
receptor for vasoactive intestinal polypeptide. Neuron 1992; 8: 811-819.

6. Lutz EM, Sheward WJ, West KM, Morrow JA, Fink G, Harmar AJ. The VIP2 receptor: molecular characterisation of a cDNA encoding a novel receptor for vasoactive intestinal peptide. FEBS Lett 1993; 334: 3-8.

7. Sreedharan SP, Huang JX, Cheung MC, Goetzl E. Structure, expression, and chromosomal localization of the type I human vasoactive intestinal peptide receptor gene. Proc Natl Acad Sci USA 1995; 92: 2939-2943.

8. Busto R, Prieto JC, Bodega G, Zapatero J, Carrero I. Immunohistochemical localization and distribution of VIP/ PACAP receptors in human lung. Peptides 2000; 21: 265269.

9. Groneberg DA, Hartmann P, Dinh QT, Fischer A. Expression and distribution of vasoactive intestinal polypeptide receptor VPAC2 mRNA in human airways. Lab Invest 2001; 81: 749-755.

10. Lucchini R, Facchini F, Turato G, et al. Increased VIPpositive nerve fibers in the mucous glands of subjects with chronic bronchitis. Am J Respir Crit Care Med 1997; 156: 1963-1968.

11. American Thoracic Society. Standards for the diagnosis and care of patients with chronic obstructive pulmonary disease. Am J Respir Crit Care Med 1995; 152: S77-S121.

12. NHLBI/WHO workshop report. Global initiative for chronic obstructive lung disease. Global strategy for the diagnosis, management, and prevention of chronic obstructive pulmonary disease. Bethesda, National Institutes of Health, National Hearth, Lung, and Blood Institute, 2001; pp. 7.

13. Saetta M, Di Stefano A, Maestrelli P, et al. Airway eosinophilia in chronic bronchitis during exacerbations. Am J Respir Crit Care Med 1994; 150: 1646-1652.

14. Miotto D, Hollenberg MD, Bunnet NW, et al. Expression of protease activated receptor-2 (PAR-2) in central airways of smokers and non-smokers. Thorax 2002; 57: 146-151.

15. Miotto D, Ruggieri MP, Boschetto $\mathrm{P}$, et al. Interleukin-13 and -4 expression in the central airways of smokers with chronic bronchitis. Eur Respir $J$ 2003; 22: 602-608.

16. Carstairs JR, Barnes PJ. Visualization of vasoactive intestinal peptide receptors in human and guinea pig lung. J Pharmacol Exp Ther 1986; 239: 249-255.

17. Ghatei MA, Sheppard M, O'Shaunessy DJ, et al. Regulatory peptides in the mammalian respiratory tract. Endocrinology 1982; 111: 1248-1254.

18. Tokunaga T, Kiso T, Namikawa T, Ohtsubo Y. cAMPindependent chloride secretion activated by a vasoactive intestinal peptide in a monolayer culture of human bronchial epithelial cells. Biol Pharm Bull 1999; 22: 745-748.

19. Sakai N, Tamaoki J, Kobayashi T, et al. Vasoactive intestinal peptide stimulates ciliary motility in rabbit tracheal epithelium: modulation by neutral endopeptidase. Regul Pept 1991; 34: 33-41.

20. Mullol J, Baraniuk JN, Pitale M, et al. Vasoactive intestinal peptide (VIP) induces IL-6 and IL-8, but not G-CSF and
GM-CSF release from a human bronchial epithelial cell line Neuropeptides 1997; 31: 119-124.

21. Chen Y, Thai P, Zhao YH, Ho YS, DeSouza MM, Wu R Stimulation of airway mucin gene expression by interleukin (IL)-17 through IL-6 paracrine/autocrine loop. J Biol Chem 2003; 278: 17036-17043.

22. Rogers DF. Motor control of airway goblet cells and glands. Respir Physiol 2000; 125: 129-144.

23. Gomariz RP, Martinez C, Abad C, Leceta J, Delgado M. Immunology of VIP: a review and therapeutical perspectives. Curr Pharm Des 2001; 7: 89-111.

24. Lara-Marquez ML, O'Dorisio MS, O'Dorisio TM, Shah M, Karacay B. Selective gene expression and activation-dependent regulation of vasoactive intestinal peptide receptor type 1 and type 2 in human T cells. J Immunol 2001; 166: 25222530.

25. Schratzberger P, Geiseler A, Dunzendorfer S, et al. Similar involvement of VIP receptor type I and type II in lymphocyte chemotaxis. J Neuroimmunol 1998; 87: 73-81.

26. Delgado M, Pozo D, Martinez C, et al. Vasoactive intestinal peptide and pituitary adenylate cyclase-activating polypeptide inhibit endotoxin-induced TNF-alpha production by macrophages: in vitro and in vivo studies. J Immunol 1999; 162: $2358-2367$.

27. Delgado M, Munoz-Elias EJ, Gomariz RP, Ganea D. Vasoactive intestinal peptide and pituitary adenylate cyclase-activating polypeptide enhance IL-10 production by murine macrophages: in vitro and in vivo studies. J Immunol 1999; 162: 1707-1716.

28. Jiang X, Wang HY, Yu J, Ganea D. VIP1 and VIP2 receptors but not PVR1 mediate the effect of VIP/PACAP on cytokine production in T lymphocytes. Ann N Y Acad Sci 1998; 865: 397-407.

29. Delgado M, Leceta J, Gomariz RP, Ganea D. Vasoactive intestinal peptide and pituitary adenylate cyclase-activating polypeptide stimulate the induction of Th2 responses by upregulating B7.2 expression. J Immunol 1999; 163: 3629-3635.

30. Voice JK, Dorsam G, Lee H, Kong Y, Goetzl EJ. Allergic diathesis in transgenic mice with constitutive $\mathrm{T}$ cell expression of inducible vasoactive intestinal peptide receptor. FASEB J 2001; 15: 2489-2496.

31. Pakbaz H, Foda HD, Berisha HI, Trotz M, Said SI. Paraquat-induced lung injury: prevention by VIP and the related peptide helodermin. Am J Physiol 1993; 265: L369L373.

32. Said SI, Berisha HI, Pakbaz H. Excitotoxicity in lung: Nmethyl-D-aspartate-induced, nitric oxide-dependent, pulmonary edema is attenuated by vasoactive intestinal peptide and by inhibitors of poly (ADP-ribose) polymerase. Proc Nat Acad Sci USA 1996; 93: 4688-4692.

33. Delgado M, Gomariz RP, Martinez C, Abad C, Leceta J. Anti-inflammatory properties of the type 1 and type 2 vasoactive intestinal peptide receptors: role in the lethal endotoxic shock. Eur J Immunol 2000; 30: 3236-3246. 